\title{
WOMEN'S PARTICIPATION IN POLITICS AND GOVERNMENT: THE EXPERIENCE OF THE UNITED ARAB EMIRATES AND OF CHINA
}

\author{
Yuliya Levchenko \\ Postgraduate Student of the Faculty of Philosophy, \\ Taras Shevchenko National University of Kyiv, Ukraine \\ e-mail: levchenko2629@gmail.com, orcid.org/0000-0002-3851-5355
}

\section{Summary}

The article analyzed the political participation of women in the context of politics and governance in the UAE and China. A comparative analysis of women's political participation in the context of politics and governance in the UAE and China based on data analysis: official state information sources of these countries and reports of international monitoring missions, women's rights organizations, impartial scientists and researchers on women's rights, gender equality, women's representation in politics and government, their political participation. The author's hypothesis was confirmed: women are presented in state institutions in public positions, but they are not represented in local governments (they are not accepted in society itself), the real women's political participation and representation of women in politics and government of UAE and China is unsatisfactory, and the states deliberately produces false information about the situation regarding women's rights and gender equality.

Keywords: women's political participation, women's participation in decision-making, UAE policies and governance, China policies and governance, international standards.

\section{DOI: https://doi.org/10.23856/4814}

\section{Introduction}

The stereotypical perception of the UAE and China as traditionalist countries has been shattered for more than 20 years. Traditionally rigid patriarchal societies with a dominance of male power in the family and society, these countries have a long tradition of granting women fairly broad rights. These countries are innovating and empowering women as a result of demands dictated by changes in the world economy and under pressure from the international community. Both countries will make significant efforts to demonstrate and maintain the image of advanced countries in order to establish relations with the world community. On the contrary, are there representatives within the political elites who are really interested in building society and expanding women's political participation and representation in politics and government?

China and the UAE are implementing and developing initiatives for women's political participation and representation in self-government and government institutions, but the scale of these changes and women's real access to socially meaningful decision-making remain questionable. The aim of this study is to examine the patterns of public and political representation of women in government and in the political sphere at various levels to determine the credibility and sincerity of the UAE and China's intentions to build the legal system and achieve gender equality. Both countries demonstrate an intention to promote women in community initiatives and ensure their participation and representation: if women are in public institutions in public positions, but they are not represented in local governments (they are not accepted in society 
itself), then real women's political participation and representation women in politics and government is unsatisfactory. Attention should be paid to the extent to which information on the situation of women's rights is controlled and whether each of the states deliberately produces fakes about the situation regarding the observance of women's rights and gender equality.

\section{Methodology}

The method of comparative research was used, based on existing relevant research and official statistics of state and international organizations. A critical analysis of the sources was also used: in the case where the data from the sources of the states under consideration could be biased, data collected by independent academic researchers were used. For each target country, official government sources on women's rights, gender equality, women's representation in politics and governance, their political participation, reports from international monitoring missions and women's rights organizations on the same subject were reviewed and compared. Government sources tend to cover externally oriented information (tailored to the needs of interaction with partners), while reports from international organizations and impartial scientists and researchers contain a realistic assessment of the situation.

\section{Results and Discussion}

\section{Women's political participation in the context of politics and governance in China}

Chinese women play an important role in many aspects of socio-economic activity. However, the overall political participation of women in China has not improved significantly in recent decades. The heterogeneous form of women's representation in government will not support a steady improvement in women's participation in politics in China. The document argues that high-ranking women politicians will promote political gender equality, but greater participation in politics by the lower female population is more important and fundamental. Therefore, a proactive policy on women's participation in politics will work well only when it focuses not only on the middle level of government, but also on the participation of grassroots groups. A recent national survey in China revealed important information for an in-depth analysis of women's participation in politics. The most important documents that had a significant impact on political decisions and the direction of state policy in relation to gender equality were the Convention on the Elimination of All Forms of Discrimination against Women (CEDAW) and The Program of Action of the World Conference on Women in Beijing in 1995 (Zhao, 2017; Fan \& Jiang, 2019).

This result is consistent with the official statistics above, which show the poverty of women in management positions. In decision-making positions, women are at a complete disadvantage. The dominant explanation for the underrepresentation of women in lower structures and in politics in general focuses on women's lack of self-confidence and the relentless involvement of "feudal" attitudes (for example, women are considered inferior to men). More than half of the people surveyed (61.6\% of men and $54.6 \%$ of women) agreed that "the field for men is public and the domain for women is in the household" (All-China Federation of Women and National Bureau of Statistics of China 2011). This seems to suggest that people tend to believe that women are not by nature political or social creatures, which means that traditional ideology about the role of women hinders the improvement and promotion of gender equality, especially regarding women's participation in politics. It can be concluded that this situation is deteriorating, it should be noted that the number of people who adhere to this view has 
increased by 7.7 and 4.4 percentage points, respectively, for men and women compared to 2000 (All-China Federation of Women and National Bureau of Statistics). China 2011). However, the real situation looks more complex as societal practices, economic structures, institutional norms, procedures, and political cultures reflect, revitalize, and reproduce gender perceptions of the proper place of women and men in political life (Tong, 2021).

Political participation is not only holding formally representative positions in parliaments or local governments, but also in a wider range of leadership roles, reflecting representation in management and citizenship, such as leadership in leading companies, membership in central government councils and bodies, and so on. From the general point of view of citizenship, political participation is the primary human right, duty and responsibility of citizens to engage in broad public affairs, which does not require them to take political positions. In this regard, women's participation in public and mass organizations and grassroots organizations is an important indicator of women's political participation (Zhao, 2017; Fan \& Jiang, 2019).

The political representation of women in modern China reaches certain global averages and lags far behind the countries that have become leaders in implementing gender equality. In particular, the results of the elections to the representative party bodies before the 19th Congress of the CCP showed that in the 90 million CCP about $25 \%$ of women, about the same as in the Chinese Parliament. At the same time, only 33 women (9\%) joined the Central Committee of the party, and only two (8\%) joined the Politburo. It should be borne in mind that in terms of the level of political representation of women in higher authorities, China has significantly surpassed countries such as the United States, India and Russia (Women in politics, 2021). Today, Sun Chunlan's is alone woman among the four vice-premiers of the Chinese government, the State Council of the People's Republic of China. In accordance with the tradition of most gender-sensitive governments, which transfer to women areas that are not crucial in state policy, she oversees science and education, culture, health and sports. The State Committee for Health and Childbirth Planning is headed by Li Bin. Of the 31 members of the Chinese government, only one represents women (Women in politics, 2021).

An analysis of the real activities of Chinese women's organizations, including the AWF, as well as the personalities and social status of their leaders (in the case of the AWF, Shen Yuyue, one of the most prominent party functionaries close to former Chinese party leader $\mathrm{Hu}$ Jintao), points to their limitations. These organizations are mainly engaged in the fight against poverty, contribute to the construction of socialism "with a Chinese face" and so on. That is, their activities do not focus on women's issues and gender issues as such (Yihong, 2020).

Chinese researchers Qing and Hee point out that such an approach to the exercise of power in society is an attempt by the authoritarian government to implement "democratic" innovations in the form of "phantom democracy" or an analogue of Rodan's idea of participation in governance without democracy ( $Q$ in \& He, 2021). Some Chinese researchers call the blatant demonstration of Chinese women's equality a "digital carnival" because it hides tight control over feminist organizations, suppresses attempts to spread the anti-harassment movement in the university environment, and opposes domestic violence (Tan, 2017; Zhang $\& X u, 2018)$.

Women mostly join the party for career reasons while studying at university or at work. Public opinion gives a woman the place of a housewife, mother and wife, so do not expect ambition from her. It is extremely rare for women to be able to rise above the local, city or provincial level of government. At the same time, functional segregation, i.e. the restriction of women to certain types of administrative, managerial, or governmental functions, is not observed in China ( $\mathrm{He} \& \mathrm{Wu}, 2017)$. 
Women's political participation and public presence in the context of politics and governance in $U A E$

In the UAE, conventions protecting women's rights have been tariffed, in particular the Convention on the Elimination of All Forms of Discrimination against Women. A law has been in force since 2011, according to which children born to an UAE citizen and a man of another nationality can acquire national citizenship. Such changes meet the real demographic situation, as there are significantly more foreigners living in the UAE who have come temporarily or permanently to do business or perform employment contracts than locals (Elessawy, 2018). Most of the significant changes that have taken place in the UAE regard to the situation of women concern the economic side of life, education and the exercise of the right to self-disposition of property and property of various types. These changes have taken place over the last two decades, and today most young women seek education before marrying and having children. As a result, the average age of birth of the first child for the country has shifted to 28 years, while two decades ago, traditionally at 13 - 14 years, immediately after marriage, a woman gave birth to her first child. The traditional approach, which still dominates in some other countries in the region, is to completely isolate women from social life and focus on family life and caring for children and husbands (Miller, Kyriazi \& Paris, 2017).

In the current UAE government, 8 of the 29 members of the government are women, the share of women in parliament was $23 \%$ in 2016 , while in 1990 women were not represented in parliament at all. Women play a significant role in the diplomatic corps, where they make up $20 \%$ of the total diplomatic corps. However, there are no women with the rank of Ambassador Extraordinary and Plenipotentiary. The vast majority of young women receive higher education, in particular, $71.6 \%$ of students in UAE universities are women, and $95 \%$ of girls and $80 \%$ of men go to university after school. According to experts, the gender shift towards women is due to the fact that men in the UAE seek a prestigious education abroad, while women can only afford national higher education, which has a relatively lower level than in developed countries (Abdulkadir \& Müller, 2020).

Legally, women in the UAE receive equal pay for equal work. They are free to work in their chosen jobs, including in government - but only with the consent of their guardian, who is usually their father. In fact, two-thirds of public sector jobs are held by women, and women make up about $40 \%$ of the total workforce. Pregnant women are guaranteed paid maternity leave, although the duration of the leave and its full or half payment depends on the place of work. There is no official leave for the father (Carvalho Pinto, 2019). Women in the UAE are free to start a business, and in recent years there has been a desire to support them. More and more groups of women-led entrepreneurs, such as Womena, are talking about women entrepreneurs in the Emirates. At present, women's business owners make up 10\% of the UAE's private sector and hold $15 \%$ of seats on chambers of commerce and industry across the country (Miller, Kyriazi \& Paris, 2017).

Financial and property rights women from the Emirates are free to buy real estate and get a mortgage. In fact, a recent study found that $30 \%$ of property in Dubai belongs to women. However, it is important for women to make a will, as Islamic law stipulates that the size of the inheritance depends on the sex of the heir; interest is higher for male heirs. The UAE is a highly literate country, with a literacy rate of about $95 \%$ for men and women. Women have access to all levels of education, including primary and secondary school. In fact, $77 \%$ of women in the Emirates enter higher education after high school. Women make up $70 \%$ of all university graduates (Miller, Kyriazi \& Paris, 2017). 
In the Gender Gap Ranking for 2021, the UAE ranks 135th on women's economic participation; by 89 in terms of educational opportunities; 130 for health and safety; the list of 155 countries by political representation of UAE women did not get into the ranking at all. China ranked 69th in terms of women's economic participation; according to opportunities for education - 103rd; by level of safety and health - 156 (last in the ranking); by level of political representation - 118 (Global Gender Gap Report, 2021). It is easy to see that, according to independent international experts, both countries, despite their economic power and persistent efforts to present extraordinary achievements in women's equality and their political representation and access to decision-making, are extremely vulnerable.

\section{Conclusion}

The government and ruling elites of the PRC and the UAE are dominantly male but make great efforts to represent their efforts to achieve gender equality on the international stage. Analysis of statistical information and the real representation of women in local and supreme government bodies demonstrate that these efforts are more informational and presentational in nature. The status of women in both countries is improving significantly in the areas of education, legal rights and employment, and health care. At the same time, women's political representation and women's real access to the process of determining state or local policy and decision-making are extremely limited, which is confirmed by the corresponding ratings provided to both countries by international observers.

Women receive rights to manage property and broader rights to education, work in research institutions and for business; thus, they are more involved in the production of goods, but they practically do not get a greater opportunity to control the distribution of these goods or to pass legislation and make decisions.

\section{References}

Abdulkadir, R., \& Müller, H. (2020). The Politics of Women Empowerment: Female Leaders in the UAE. Hawwa, 18(1), 8-30.

All-China Women's Federation \& National Bureau of Statistics of China (2011). Report on Major Results of the Third Wave Survey on The Social Status of Women in China. Retrieved from: www.wsic.ac.cn/academicnews/78621.htm.

Carvalho Pinto, V. (2019). Signalling for status: UAE and women's rights. Contexto internacional, 41, 345-363.

Edwards, L. (2020). Women in the People's Republic of China: New challenges to the grand gender narrative. In Women in Asia (pp. 59-84). Routledge.

Elessawy, F. (2018). The Embodied Impact of Immigrant Guest Workers on the Urban Demography of Dubai City. Bulletin de la Société de Géographie d'Egypte, 91(1), 28-47.

Fan, H., \& Jiang, X. (2019). The Evaluation and Analysis of the Government's Entity Responsibilities of Promoting Gender Equality and Women's Development. J. Hum. Rts., 18, 336.

Federation, A. C. W. S. (2015). Gender Equality and Women's Development in China. Retrieved from: http://www.scio.gov.cn/zfbps/ndhf/2015/Document/1449894/1449894.htm.

He, G., \& Wu, X. (2017). Marketization, occupational segregation, and gender earnings inequality in urban China. Social Science Research, 65, 96-111.

Miller, K., Kyriazi, T., \& Paris, C. M. (2017). Arab women employment in the UAE: exploring opportunities, motivations and challenges. International Journal of Sustainable Society, 9(1), 20-40. 
Qin, X., \& He, B. (2021). The politics of authoritarian empowerment: Participatory pricing in China. International Political Science Review, 0192512120985511.

Tan, J. (2017). Digital masquerading: Feminist media activism in China. Crime, Media, Culture, 13(2), 171-186.

Tong, X. (2021). Policies for Promoting the Growth of Female Leaders in Politics. In Career Patterns and Policies of Female Leaders in China (pp. 379-392). Springer, Singapore.

Women in politics: 2021. Режим достуny: https://www.unwomen.org/en/digital-library/publications/2021/03/women-in-politics-map-2021

Yihong, J. (2020). The all China women's federation: challenges and Trends. In Chinese Women Organizing (pp. 123-140). Routledge.

Zhang, N., \& Xu, W. (2018). Discovering the positive within the negative: The women's movement in a changing China. In The challenge of local feminisms (pp. 25-57). Routledge. Global Gender Gap Report 2021. INSIGHT REPORT. MARCH 2021. Режим достуny: http://www3.weforum.org/docs/WEF_GGGR_2021.pdf

Zhao, Y. (2017). (Un) doing Gender Equality in China. In Gender Equality in a Global Perspective (pp. 77-100). Routledge. 